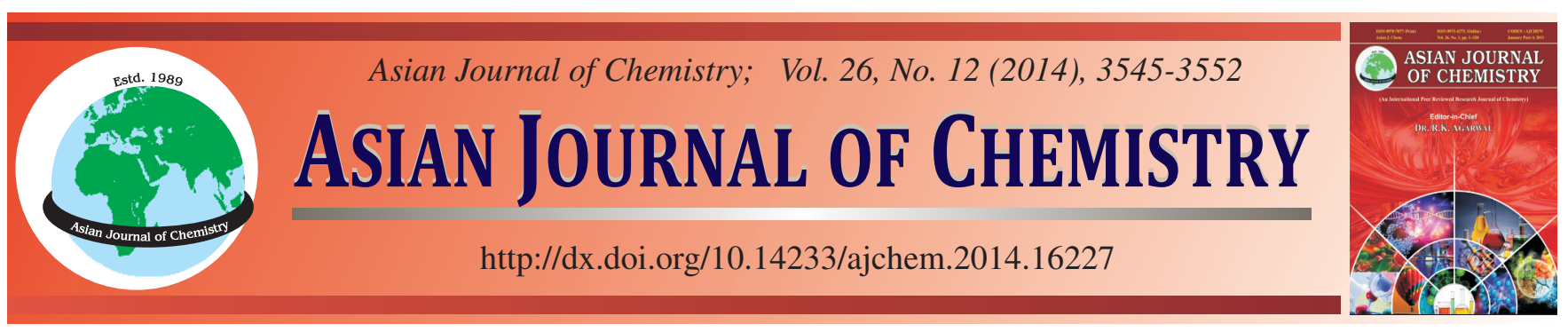

\title{
Removal of Phosphate by Paper Mill Sludge: Adsorption Isotherm and Kinetic Study
}

\author{
Sharifah Mohamad ${ }^{1, *}$, Nor Kartini Abu Bakar ${ }^{1}$, Ahmad Razali IshaK ${ }^{1,2}$, Hemavathy Surikumaran ${ }^{1}$, \\ Kavirajaa Pandian ${ }^{1}$, Muggundha Raoov ${ }^{1,3}$, Nur Nadhirah Mohamad Zain ${ }^{1,3}$ and Kumuthini Chandrasekaram ${ }^{4}$
}

\begin{abstract}
${ }^{1}$ Department of Chemistry, Faculty of Science, University of Malaya, Kuala Lumpur 50603, Malaysia
${ }^{2}$ Department of Environmental Health, Faculty of Health Science, University of Teknologi Mara, Puncak Alam, 42300 Kuala Selangor, Malaysia ${ }^{3}$ Cluster Integrative Medicine, Advanced Medical \& Dental Institute, Universiti Sains Malaysia, No 1-8 (Lot 8), Persiaran Seksyen 4/1, Bandar Putra Bertam, Kepala Batas, Pulau Pinang 13200, Malaysia

${ }^{4}$ University of Malaya Centre for Ionic Liquids, Department of Chemistry, Faculty of Science, University of Malaya, Kuala Lumpur 50603, Malaysia
\end{abstract}

*Corresponding author: Fax: +60 3 79674193; Tel: +60 3 79676751; E-mail: sharifahm@um.edu.my

Received: 24 August 2013;

Accepted: 25 November 2013;

Published online: 5 June 2014;

AJC-15292

\begin{abstract}
Phosphate ions have been removed from aqueous solution by paper mill sludge. The influences of experimental conditions such as $\mathrm{pH}$, amount of adsorbent, initial concentration of phosphate, adsorption isotherm and adsorption kinetics of paper mill sludge were studied. The adsorption of phosphate was more efficient in the basic $\mathrm{pH}$ region $(\mathrm{pH} 12)$. Pseudo second-order model fits better than the pseudo first-order model for adsorption kinetic data and indicates the adsorption process is based on chemisorptions. The calculated activation energy $\left(\mathrm{E}_{\mathrm{a}}\right)$ is $37.01 \mathrm{~J} / \mathrm{mol}$ which further suggests that the sorption of phosphate by paper mill sludge was based on chemical adsorption. Consequently, the equilibrium isotherm data were fitted well to Langmuir isotherm with maximum adsorption capacity of $12.65 \mathrm{mg} / \mathrm{g}$. From the study, it showed that paper mill sludge has the potential to be utilized as a cost effective and high capability adsorbent for removal of phosphate from aqueous solutions.
\end{abstract}

Keywords: Paper mill sludge, Phosphate, Removal, Kinetics, Adsorption.

\section{INTRODUCTION}

Industrial sectors play an important role in the growth of the world economy by providing services and products that improve the quality of people's lifestyle. However, the rapid industrialization generates huge amounts of wastes which greatly affect the environment. The increasing amounts of industrial wastes require a larger space of landfill and expensive treatment for disposal. This causes a detrimental pollution effect on the soil, water and air ${ }^{1}$. One of the industries that generate quite large amounts of industrial waste is the pulp and paper production. This industry produces large amount of sludge as a result from their wastewater treatment plant. The primary method of disposal for paper mill sludge is mainly through land application and land filling ${ }^{2}$. Land filling costs are rising because of stringent regulation, taxes and declining capacity. With landfill space becoming scarce and expensive, sludge are being burned or incinerated to reduce their volume and to recover part of the energy that they contain ${ }^{3}$. Expensive treatment of land disposal necessitates other means of treatment which is more economical and other alternatives used of these waste for beneficial application.
A recent alternative method to overcome this problem is by utilization of the industrial waste for other valuable applications. This alternative method allows the industrial sector to reduce the cost of disposal and at the same time reduces the cost of the manufacturing process, enhances the efficiency of resource utilization and most importantly reduces the negative impacts on the environment and human health. Utilization of waste material for other valuable applications will balance the increasing demands of limited natural resources by providing alternative resources and reduces the dependency on natural resources $^{1}$.

Paper mill sludge is mainly composed of organic matter which is added to the paper or pulp whereas inorganic compounds (mainly calcium carbonate, kaolinite and talc) are used as fillers and coating ${ }^{4}$. Some studies had been done using material containing calcium such as fly ash and calcite to remove phosphate from waste water ${ }^{5}$. In view of the fact that the calcium content in the paper mill sludge is high, hence we investigated the efficiency of paper mill sludge as adsorbent for removal of phosphate from aqueous solution. Phosphate wastes are usually being discharged into rivers causing harmful effects to the environment and human health ${ }^{6}$. The excess of phosphate will 
cause eutrophication which will lead to imbalance to an ecosystem. Recently, phosphate is treated using chemical, biological and physical treatment processes which have their own advantages and disadvantages. However, these processes are expensive. In addition, employing environmental friendly methods for treatment is emphasized much more these days. The utilization of paper mill sludge as adsorbent for phosphate removal could help in this regard, in addition to re-using of these waste materials, which can be an advantage.

Considering the environmental problems from both solid waste of paper mill sludge and phosphate contamination, the removal of phosphate using paper mill sludge will be a good solution for both problems. Most researchers studied the removal of phosphate by modification of paper mill sludge before using it for phosphate removal ${ }^{7-10}$. Nevertheless, in this study, raw paper mill sludge was used for phosphate adsorption without any modification. The use of paper mill sludge as an adsorbent was studied and optimized under different controlling parameters including the effects of $\mathrm{pH}$, initial concentration of phosphate, dosage of paper mill sludge and the contact time. The adsorption kinetics and adsorption isotherm of phosphate were also investigated.

\section{EXPERIMENTAL}

Functional groups of adsorbent were investigated using the fourier transform infrared spectrometry (FTIR). The spectra were recorded on a Perkin Elmer FTIR RX1 Spectrophotometer at ambient temperature using a KBr disk method. Qualitative analysis of calcite using X-ray diffraction (XRD) was carried out by using XRD Siemens D5000 diffraction with $\mathrm{CuK}_{\alpha}$ radiation $(\lambda=0.15406 \mathrm{~nm})$.

Artificial orthophosphate standard solutions were used throughout the adsorption test. A stock solution of $1000 \mathrm{mg} / \mathrm{L}$ in orthophosphate was prepared by dissolving a certain amount of chemically pure sodium dihydrogen orthophosphate in ultrapure water. An aliquot of the stock solution was further diluted with ultrapure water to prepare the desired experimental concentrations. All standards are daily prepared to avoid possible precipitation of phosphate species. IC effluent was prepared using sodium bicarbonate and sodium carbonate in the ratio of 8:1. The effluent was daily prepared to maintain effluent quality and condition for phosphate quantification.

Sampling of paper mill sludge: Paper mill sludge sample was collected from Union Paper Industries Sdn. Bhd. in Bentong, Pahang, Malaysia. The paper mill sludge was collected randomly and packed in plastic bags before keeping it in the freezer prior to experimental steps.

Preparation of adsorbent material: Paper mill sludge was first crushed mechanically with a jaw crusher then it was dried in an oven at $110^{\circ} \mathrm{C}$ for $24 \mathrm{~h}$ and then crushed again. Samples were sieved and stored in the desiccators.

Adsorption measurement: The batch experiment was carried out with a defined amount of adsorbent sample in a $100 \mathrm{~mL}$ bottle sample. A defined volume of the phosphate concentration was prepared from a stock solution by adding ultra pure water. The $\mathrm{pH}$ of the phosphate solution was then adjusted to the desired value and added to the bottle container. The mixture was stirred at $200 \mathrm{rpm}$ for a defined period. After a certain period of stirring, filtering process was applied to separate solid from liquid. The supernatant was then subjected to ion chromatography for analysis. The amount of phosphate adsorbed per unit mass of the adsorbent $\left(\mathrm{Q}_{\mathrm{e}}\right)$ was calculated as follows:

$$
\mathrm{Q}_{\mathrm{e}}=\frac{\left(\mathrm{C}_{\mathrm{o}}-\mathrm{C}_{\mathrm{e}}\right) \mathrm{V}}{\mathrm{W}}
$$

The percentage of adsorbate adsorbed on the polymer (removal efficiency, R (\%)) was calculated by the following equation:

$$
\mathrm{R} \%=\frac{\mathrm{C}_{\mathrm{o}}-\mathrm{C}_{\mathrm{e}}}{\mathrm{C}_{\mathrm{o}}} \times 100
$$

where, $\mathrm{C}_{\mathrm{o}}$ and $\mathrm{C}_{\mathrm{e}}$ are the intial and equilibrium concentration of solutions $(\mathrm{mg} / \mathrm{L})$, respectively. $\mathrm{V}(\mathrm{L})$ is the volume of the solution and $\mathrm{W}(\mathrm{g})$ is the mass of dry adsorbent used.

\section{RESULTS AND DISCUSSION}

To ascertain the presence of functional groups in the paper mill sludge, FT-IR spectra was employed. Fig. 1 shows the FTIR spectrum of paper mill sludge. The observed features between $3500-3000 \mathrm{~cm}^{-1}$ and the band around $2900-2800 \mathrm{~cm}^{-1}$ could be attributed to $\mathrm{O}-\mathrm{H}$ group of cellulose and the $\mathrm{CH}_{2}$ groups, respectively. The bond at $1630 \mathrm{~cm}^{-1}$ was mainly assigned to the $\mathrm{O}-\mathrm{H}$ group. This $\mathrm{O}-\mathrm{H}$ group is the characteristic of the deformation vibration of $\mathrm{O}-\mathrm{H}$ group. The presence of $\mathrm{CaCO}_{3}$ leads to a broad band at $1416 \mathrm{~cm}^{-1}$ indicates the abundance of calcite in the paper mill sludge. Meanwhile an absorption band at $1161 \mathrm{~cm}^{-1}$ and $1107 \mathrm{~cm}^{-1}$ could be attributed to the $\mathrm{C}-\mathrm{O}-\mathrm{C}$ bond while the band $1031 \mathrm{~cm}^{-1}$ is the vibration of glucose unit ring involving stretching of $\mathrm{C}-\mathrm{O}$ and $\mathrm{O}-\mathrm{H}$. Finally, the absorption band at $872 \mathrm{~cm}^{-1}$ corresponds to the $\mathrm{C}-\mathrm{O}-\mathrm{C}$ bond ${ }^{11}$.

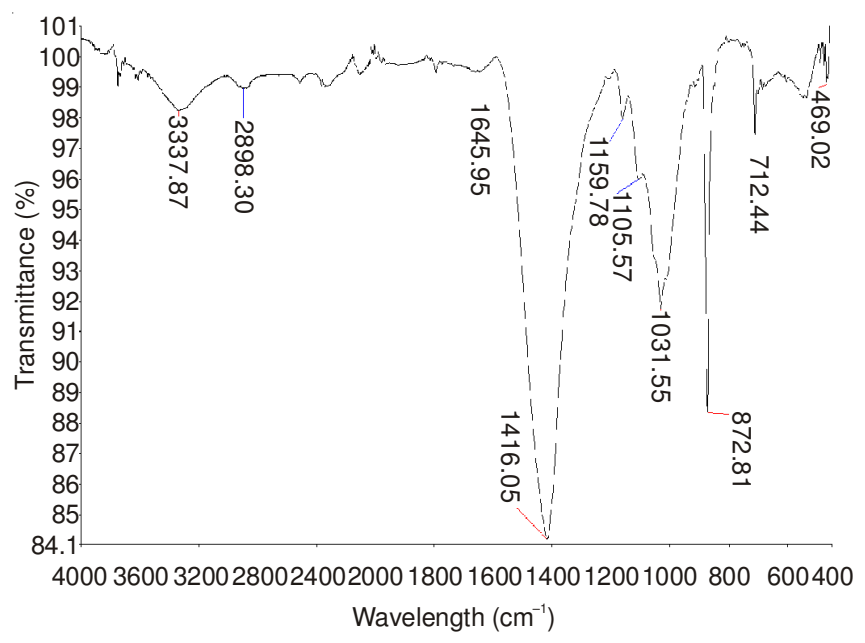

Fig. 1. FTIR spectrum of paper mill sludge

The XRD pattern of paper mill sludge (Fig. 2) shows the main crystalline constituent is calcite. The most intense peak of calcite is at $2 \theta \approx 30^{\circ}$. XRD result confirmed the abundance of $\mathrm{CaCO}_{3}$ in the paper mill sludge. The abundance of calcite in paper mill sludge is important for phosphate adsorption from water solution since its presence will enhance the reaction of calcium phosphate precipitation ${ }^{5}$. 


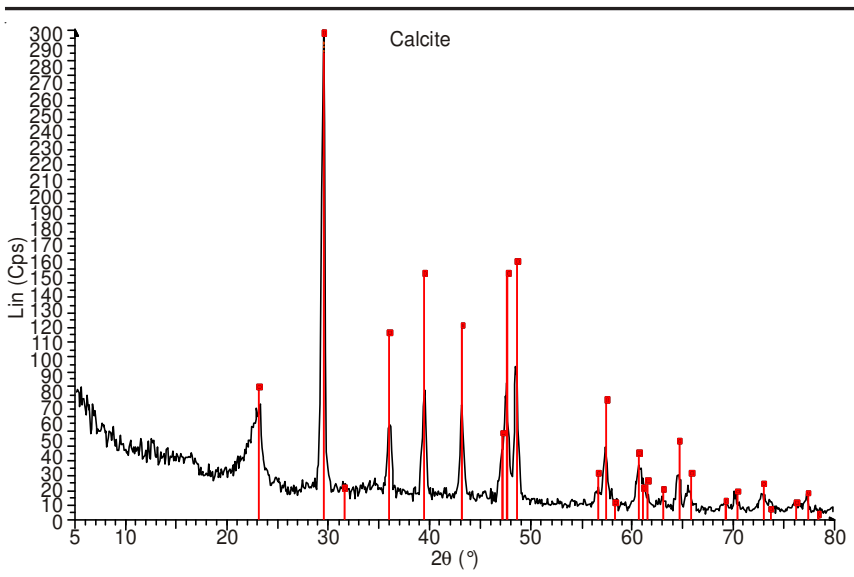

Fig. 2. XRD pattern of calcite in the paper mill sludge

\section{Adsorption properties of adsorbent}

Effect of pH on phosphate removal by paper mill sludge: The $\mathrm{pH}$ of the system is an important parameter in adsorption studies. The protonation reaction of phosphate is reported elsewhere ${ }^{5}$. It is stated that increasing of $\mathrm{pH}$ produces more negative charge to the phosphate species. $\mathrm{H}_{2} \mathrm{PO}_{4}{ }^{-}$and $\mathrm{HPO}_{4}{ }^{2-}$ species are present in the $\mathrm{pH}$ region 5-10. The concentration of $\mathrm{H}_{2} \mathrm{PO}_{4}{ }^{-}$species is higher for acidic $\mathrm{pH}$ while $\mathrm{HPO}_{4}{ }^{2-}$ species is higher in $\mathrm{pH}$ region 7-10. For $\mathrm{pH}$ between 10 and 12, $\mathrm{HPO}_{4}{ }^{2-}$ predominates, the $\mathrm{PO}_{4}{ }^{3-}$, but when the $\mathrm{pH}$ is higher than 12.5 , the concentration of $\mathrm{PO}_{4}{ }^{3-}$ becomes more significant. In this work, the effect of $\mathrm{pH}$ was examined in the $\mathrm{pH}$ region between 7 and 12 . The relationship between the initial $\mathrm{pH}$ of the solution with the adsorption capacity of phosphate is shown in Fig. 3. The adsorption capacity was increased from 0.56 to $2.21 \mathrm{mg} / \mathrm{g}$ with increasing initial $\mathrm{pH}$ from 7 to 12 . Higher content of calcite in paper mill sludge enables it to interact with phosphate species. With the increase of $\mathrm{pH}$, the deprotonation reaction of phosphate obtained more negative charges which enhance the electrostatic interaction between phosphate species and calcite in the paper mill sludge 5 . Therefore, $\mathrm{pH} 12$ was selected as the optimum $\mathrm{pH}$ for phosphate removal from solutions. The adsorption process could be possibly described by the following reaction:

$$
\begin{aligned}
& \mathrm{Ca}^{2+}+\mathrm{H}_{2} \mathrm{PO}_{4}^{-} \longrightarrow \mathrm{CaH}_{2} \mathrm{PO}_{4}{ }^{+} \\
& \mathrm{Ca}^{2+}+\mathrm{HPO}_{4}{ }^{2-} \longrightarrow \mathrm{CaHPO}_{4} \\
& \mathrm{Ca}^{2+}+\mathrm{PO}_{4}{ }^{3-} \longrightarrow \mathrm{CaPO}_{4}^{-}
\end{aligned}
$$

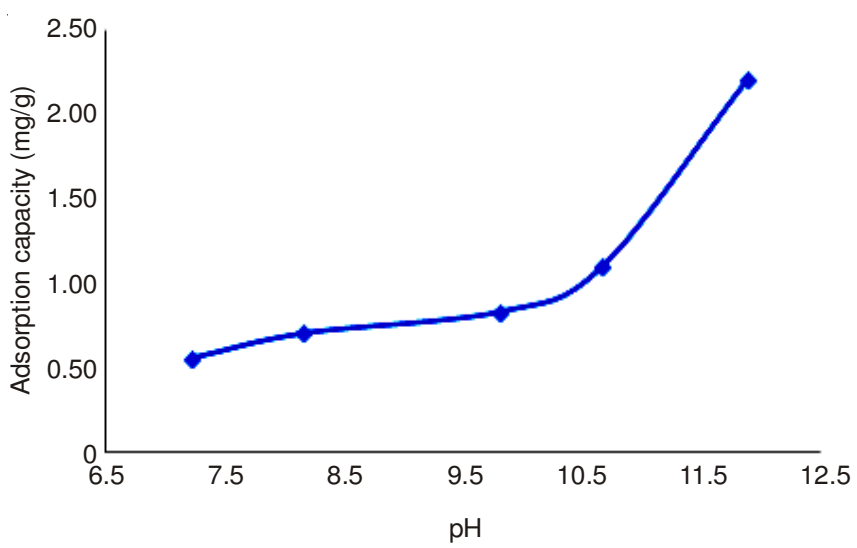

Fig. 3. Adsorption capacity of phosphate removal by paper mill sludge at various $\mathrm{pH}$ conditions
Effect of adsorbent dosage of paper mill sludge on phosphate removal: The effect of the adsorbent dosage was determined at $\mathrm{pH} 12$ with shaking time of $0.5 \mathrm{~h}$ at room temperature and $100 \mathrm{mg} / \mathrm{L}$ of initial phosphate concentration by varying the mass of adsorbent. Fig. 4 showed that the percentage of phosphate removal increased rapidly from 46 to $85 \%$ with increasing the adsorbent mass from 0.2 to $1 \mathrm{~g}$. However, the adsorption capacity decreased from 4.27 to 1.62 $\mathrm{mg} / \mathrm{g}$, respectively. The phosphate removal was greater with the increase in paper mill sludge due to the increase in surface area and adsorption sites available for adsorption. The decline in adsorption capacity is basically due to the site remaining unsaturated during the adsorption process ${ }^{12}$. The amount of paper sludge for further adsorption experiments was selected as $0.5 \mathrm{~g}$ because the phosphate removal and adsorption capacity were found to be optimum at $71 \%$ and $2.7 \mathrm{mg} / \mathrm{g}$, respectively.

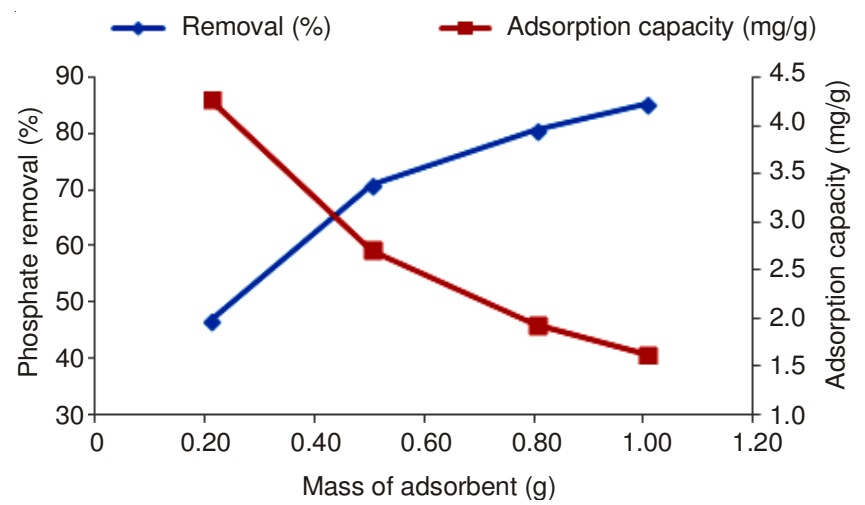

Fig. 4. Effect of adsorbent dosage of paper mill sludge on the adsorption capacity and percentage removal of phosphate

Effect of initial concentration of phosphate on adsorption: The adsorption experiments were performed to study the effect of initial phosphate concentration by varying it from 50 to $300 \mathrm{mg} / \mathrm{L}$ while maintaining the amount of paper mill sludge $(0.5 \mathrm{~g})$. Fig. 5 shows that with the increase in phosphate concentration, the percentage of removal decreased from 95 to $83 \%$ and adsorption capacity increased from 2.07 to 9.97 $\mathrm{mg} / \mathrm{g}$. The decrease in percentage removal can be explained by the fact that the adsorbent had a limited number of active sites which would become saturated above a certain concentration. The increasing phosphate concentration in paper mill sludge influences supersaturating and decreases the efficiency of the precipitating system ${ }^{13}$. The greater value in adsorption capacity was experienced with the increase in phosphate concentration due to the utilization of more active sites available in the paper mill sludge for the adsorption at higher concentration $^{14}$.

Kinetics of phosphate adsorption by paper mill sludge: The rate of phosphate adsorption by paper mill sludge was measured as a function of shaking time at three different temperatures $\left(30,45\right.$ and $\left.70{ }^{\circ} \mathrm{C}\right)$. The adsorption process of phosphate was rapid at the initial stage and slowed when approaching equilibrium (Fig. 6). The equilibrium time for phosphate adsorption can be considered at $24 \mathrm{~h}$ and becoming stable af ter longer reaction times. The kinetics results indicated that the sorption process was increased with the increase in the solution temperature from 30 to $70{ }^{\circ} \mathrm{C}$. 


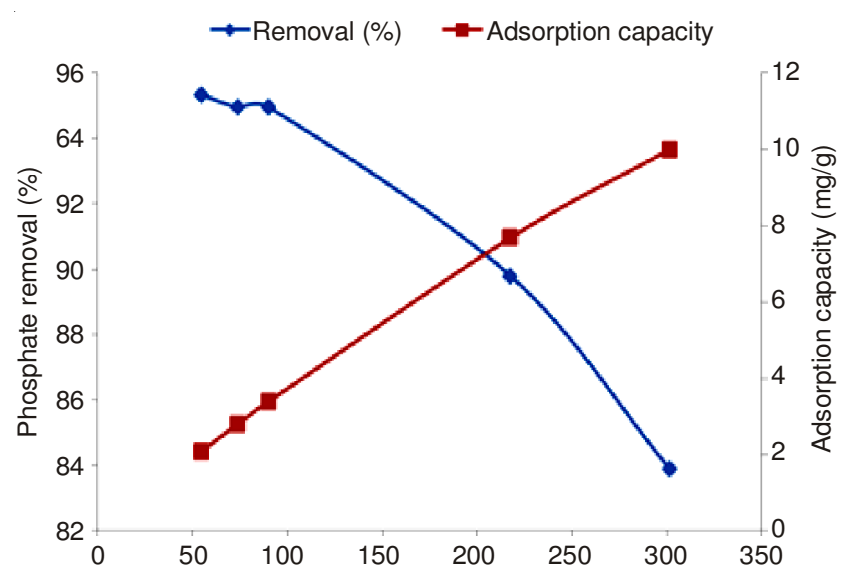

Fig. 5. Effect of initial concentration of phosphate on the adsorption capacity and percentage removal of phosphate (conditions: sorbent dosage $=0.5 \mathrm{~g}, \mathrm{pH}=12$, shaking time $=24 \mathrm{~h}$ )

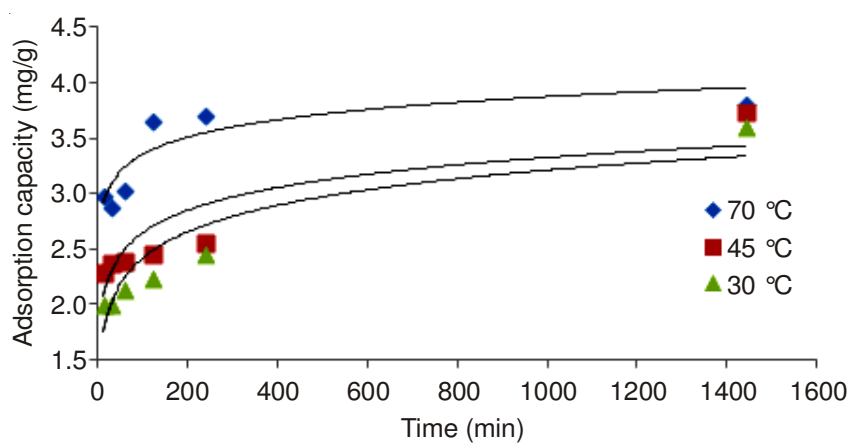

Fig. 6. Adsorption rate of phosphate by paper mill sludge (conditions: sorbent dosage $=0.5 \mathrm{~g}$, initial concentration $=100 \mathrm{mg} / \mathrm{L}, \mathrm{pH}=12$ )

The kinetics of removal of phosphate is explicitly explained in the literature using pseudo first-order, second-order kinetics models ${ }^{15,16}$, Elovich ${ }^{17}$ and intraparticle diffusion mode ${ }^{118}$. The mechanism for the removal of phosphate may involve the following four steps ${ }^{19}$ : (1) migration of the sorbate from the bulk of the solution to the surface of the sample; (2) diffusion of the sorbate through the boundary layer to the surface of the sorbent; (3) adsorption of the sorbate at an active site on the surface of the sample; (4) intraparticle diffusion of the sorbate into interior pores of the sorbent particles. The boundary layer resistance will be affected by the rate of adsorption with an increase in the contact time, which will reduce the resistance and increase the mobility of the sorbate during adsorption. Since the uptake of sorbates at the active sites of samples is a rapid process, the rate of adsorption is governed mainly by either the rate of liquid phase mass transfer or the rate of intraparticle mass transfer. Hence in this work, the sorption rates were analyzed using a pseudo first-order model (eqn. 3), a pseudo second-order model (eqn. 4), Elovich model (eqn. 5) and intraparticle diffusion kinetic model (eqn. 6) as following:

$$
\begin{gathered}
\log \left(\mathrm{Q}_{\mathrm{e}}-\mathrm{Q}_{\mathrm{t}}\right)=\log \mathrm{Q}_{\mathrm{e}}-\frac{\mathrm{k}_{1} \mathrm{t}}{2.303} \\
\frac{\mathrm{t}}{\mathrm{Q}_{\mathrm{t}}}=\frac{1}{\mathrm{k}_{2} \mathrm{Q}_{\mathrm{e}}^{2}}+\frac{1 \mathrm{t}}{\mathrm{Q}_{\mathrm{e}}} \\
\mathrm{Q}_{\mathrm{t}}=1 / \beta \ln (\alpha \beta)+1 / \beta \ln \mathrm{t}
\end{gathered}
$$

$$
\mathrm{Q}_{\mathrm{t}}=\mathrm{k}_{3} \mathrm{t}^{0.5}+\mathrm{Q}_{0}
$$

where $\mathrm{Q}_{\mathrm{e}}, \mathrm{Q}(\mathrm{t})$ and $\mathrm{Q}_{0}(\mathrm{mg} / \mathrm{g})$ are, respectively, the amounts of sorption at equilibrium, the time $t$ and the saturated state and $\left.\mathrm{k}_{1}(1 / \mathrm{min}), \mathrm{k}_{2}(\mathrm{~g} / \mathrm{mg} \min )\right)$ and $\mathrm{k}_{3}\left(\mathrm{mg} /\left(\min ^{1 / 2} \mathrm{~g}\right)\right)$ are the rate constants for pseudo first-order, pseudo second-order and intraparticle diffusion, respectively $\alpha\left(\mathrm{mg} / \mathrm{g} \mathrm{min}^{-1}\right)$ represent initial sorption rate while $\beta(\mathrm{g} / \mathrm{mg})$ is related to the extended of surface coverage and activation energy. The resulting sorption rate constants are listed in (Table-1). The correlation coefficients data for pseudo second-order model (Fig. 8) fits better than first-order kinetic model (Fig. 7) and Elovich model (Fig. 9) as shown in Table-1 for the all studied temperature with $R_{2}$ value $>0.99$. The calculated $Q_{e}$ values (Table- 1 ) were similar with the experimental values which indicate that the sorption system follows the second-order kinetic model and further confirms that the adsorption process is based on chemisorptions. The resulting phosphate sorption rate constants $\left(\mathrm{k}_{2}\right)$ for the pseudo second-order model at various temperature are clearly different, following the increasing order from 6.18 , 8.17 and 30.22 for 30,45 and $70{ }^{\circ} \mathrm{C}$, respectively and this indicates that the adsorption process is endothermic. It can be explained by the availability of more active sites of adsorbent at higher temperatures.

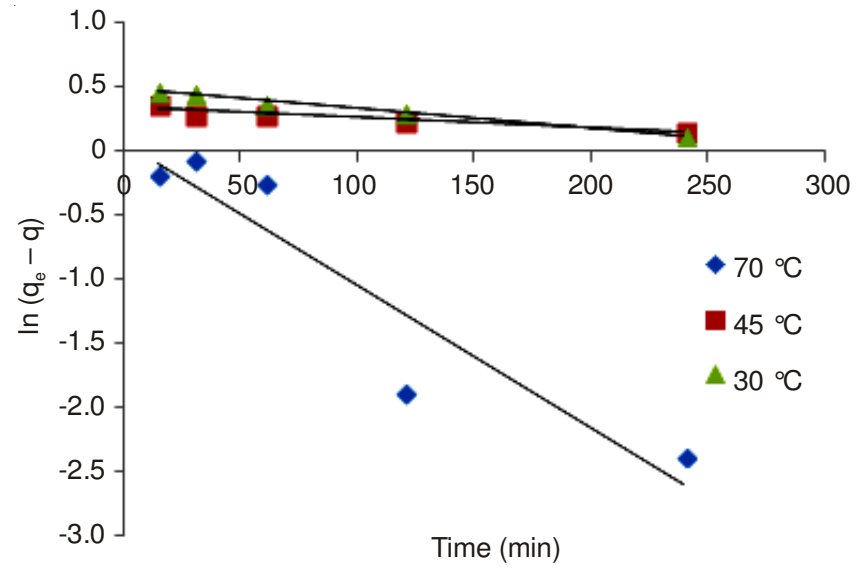

Fig. 7. First-order kinetic plot for sorption of phosphate by paper mill sludge

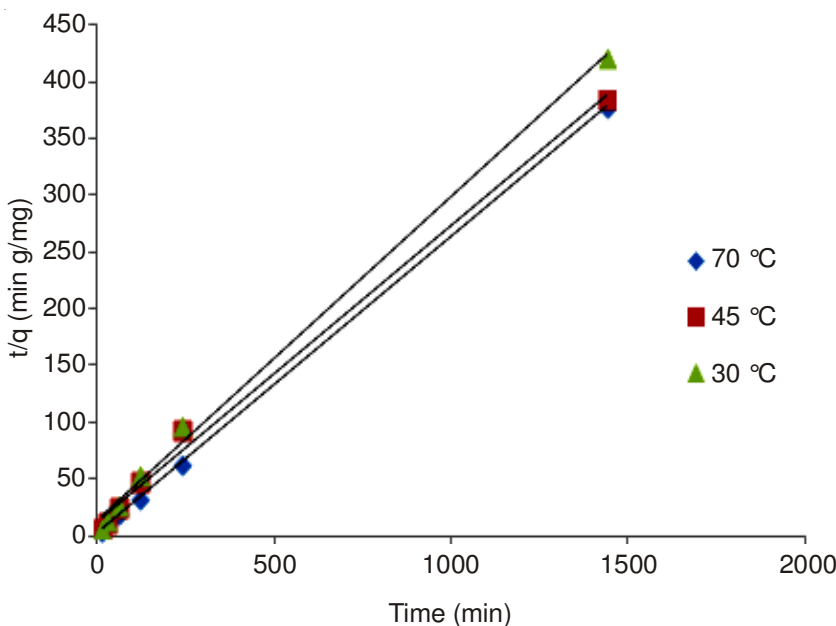

Fig. 8. Second-order kinetic plot for sorption of phosphate by paper mill sludge 


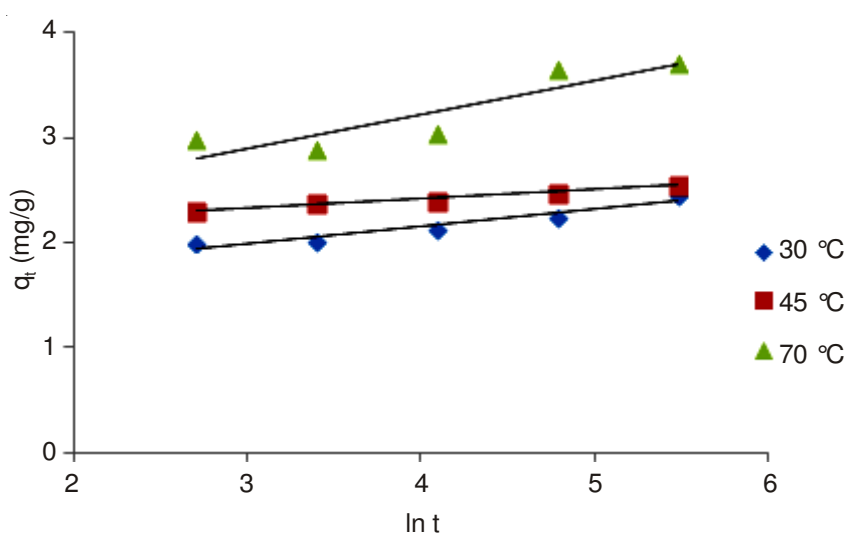

Fig. 9. Elovich kinetic plot for sorption of phosphate by paper mill sludge

Pseudo first-order, pseudo second-order models and Elovich models cannot identify the diffusion mechanism. In order to understand the mechanism of adsorption process and to determine the rate controlling step which is mainly depends on either surface or pore diffusion, intraparticle diffusion model were used $^{18}$. Weber and Morris model is adopted in this study, since this is a widely used intraparticle diffusion model. A plot of $\mathrm{Q}_{\mathrm{t}} v s . \mathrm{t}^{1 / 2}$ (square root of time) should be straight line if the sorption process follows intraparticle diffusion meanwhile if these lines pass through the origin then intraparticle diffusion would be the sole controlling step. When the plots do not pass through the origin indicates some degree of boundary layer control and proves that intrapacticle diffusion is not only rate limiting step while other processes might control the rate of adsorption, all of which may be operating simultaneously ${ }^{20}$. Fig. 10 represents a plot of linear form of intraparticle diffusion model. The result shows that the intercept did not pass through origin and correlation coefficient values $\left(\mathrm{R}_{2}\right)$ less than 0.99 (Table-1), suggesting that intraparticle diffusion was involved in the sorption process, but it was not the rate controlling step.

The rate constant, $\mathrm{k}$ depends strongly on temperature, $\mathrm{T}$. It is due to the increase in collisions which result in number of molecules having energy that exceeds the activation energy. Consequently, this will lead to rapid increase in $\mathrm{k}$ value. The $\mathrm{k}$ (T) data for many reactions can fit in the Arrhenius equation as below;

$$
\ln \mathrm{k}=\ln \mathrm{A}-\frac{\mathrm{E}_{\mathrm{a}}}{\mathrm{RT}}
$$

slope -Ea/R and intercepts ln A (Fig. 11). The magnitude of activation energy gives an idea about the type of adsorption whether it is physical or chemical ${ }^{21}$. According to the Arrhenius

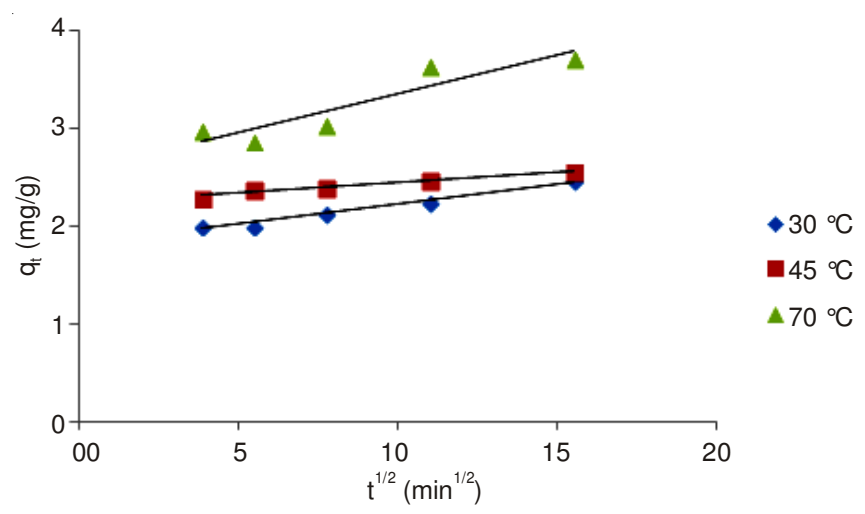

Fig. 10. Intraparticle diffusion plot for sorption of phosphate by paper mill sludge

equation, low activation energy shows a fast reaction as obtained in this study $\left(\mathrm{E}_{\mathrm{a}}=37.01 \mathrm{~J} / \mathrm{mol}\right)$. The positive activation energy indicates that the sorption of phosphate by paper mill sludge was a chemical adsorption.

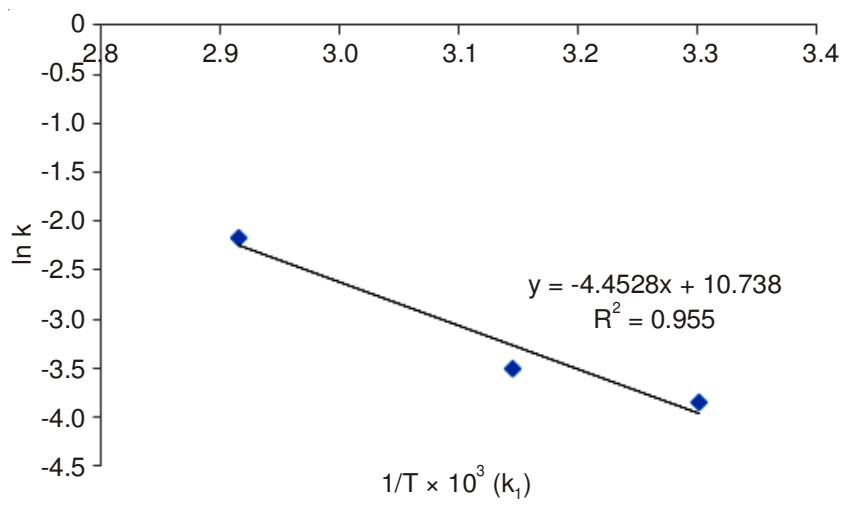

Fig. 11. Arrhenius plot for adsorption of phosphate by paper mill sludge

Adsorption isotherm of phosphate by paper mill sludge: The sorption isotherm of phosphate by paper mill sludge was measured by shaking it for $24 \mathrm{~h}$ at different initial concentrations at $\mathrm{pH} 12$ at room temperature. In this study, the isotherm data were analyzed using four different kinds of isotherm models namely Langmuir, Freundlich, D-R (DubininRadushkevich) and Temkin.

Langmuir isotherm model: The Langmuir isotherm suggests that sorption takes place on a homogeneous surface to obtain maximum adsorption capacity. No further adsorption process will occur if the site is occupied by a solute. The linear form of the Langmuir isotherm equation can be represented by the following equation ${ }^{22}$ :

TABLE-1

KINETIC PARAMETER FOR ADSORPTION OF PHOSPHATE ONTO PAPER MILL SLUDGE AT VARIOUS TEMPERATURES

\begin{tabular}{|c|c|c|c|c|c|c|c|}
\hline \multirow{2}{*}{$\frac{\text { Temp. }}{{ }^{\circ} \mathrm{C}}$} & \multirow{2}{*}{$\frac{\mathrm{Q}_{\mathrm{e}}(\operatorname{Exp})}{\mathrm{mg} / \mathrm{g}}$} & \multicolumn{3}{|c|}{ First order } & \multicolumn{3}{|c|}{ Second order } \\
\hline & & $\mathrm{k} 1 \times 10-3$ & $\mathrm{Q}_{\mathrm{e}}(\mathrm{mg} / \mathrm{g})$ & $\mathrm{R}^{2}$ & $\mathrm{k}_{2} \times 10-3$ & $\mathrm{Q}_{\mathrm{e}}(\mathrm{mg} / \mathrm{g})$ & $\mathrm{R}^{2}$ \\
\hline 70 & 3.81 & 11 & 1.08 & 0.874 & 30.22 & 3.85 & 0.999 \\
\hline 45 & 3.74 & 2 & 1.4 & 0.969 & 8.17 & 3.77 & 0.998 \\
\hline \multirow[t]{2}{*}{30} & 3.61 & 1 & 1.64 & 0.991 & 6.18 & 3.51 & 0.996 \\
\hline & \multicolumn{4}{|c|}{ Intraparticle diffusion } & \multicolumn{3}{|c|}{ Elovich } \\
\hline & & $\mathrm{k}_{3}$ & $\mathrm{Q}_{\mathrm{o}}(\mathrm{mg} / \mathrm{g})$ & $\mathrm{R}^{2}$ & $\alpha$ & $\beta$ & $\mathrm{R}^{2}$ \\
\hline 70 & & 0.078 & 2.573 & 0.838 & 5.988 & 1244.36 & 0.908 \\
\hline 45 & & 0.021 & 2.239 & 0.953 & 11.236 & $9.71 \mathrm{E}+08$ & 0.957 \\
\hline 30 & & 0.041 & 1.816 & 0.982 & 3.096 & 129.51 & 0.79 \\
\hline
\end{tabular}




$$
\frac{1}{\mathrm{q}_{\mathrm{e}}}=\frac{1}{\mathrm{bO}_{\mathrm{m}}}+\frac{\mathrm{C}_{\mathrm{e}}}{\mathrm{Q}_{\mathrm{m}}}
$$

where $\mathrm{C}_{\mathrm{e}}(\mathrm{mg} / \mathrm{L})$ is the equilibrium concentration of the adsorbate, $\mathrm{C}_{\mathrm{o}}(\mathrm{mg} / \mathrm{L})$ is the initial adsorbate concentration, $\mathrm{q}_{\mathrm{e}}(\mathrm{mg} / \mathrm{g})$ is the adsorption capacity at equilibrium, $\mathrm{Q}_{\mathrm{m}}(\mathrm{mg} / \mathrm{g})$ and $\mathrm{b}(\mathrm{L} / \mathrm{mg})$ are Langmuir constant related to maximum adsorption capacity and rate of adsorption, respectively obtained from the slope and intercept of the plot of $\mathrm{C}_{\mathrm{e}} / \mathrm{q}_{\mathrm{e}}$ and $\mathrm{C}_{\mathrm{e}}$ (Fig. 12). Furthermore, dimensionless separation factor $\left(\mathrm{R}_{\mathrm{L}}\right)$ can be calculated to determine the adsorption process is favorable or unfavorable as shown in Table-2 using the following equation;

$$
\mathrm{R}_{\mathrm{L}}=\frac{1}{1+\mathrm{bC}_{\mathrm{o}}}
$$

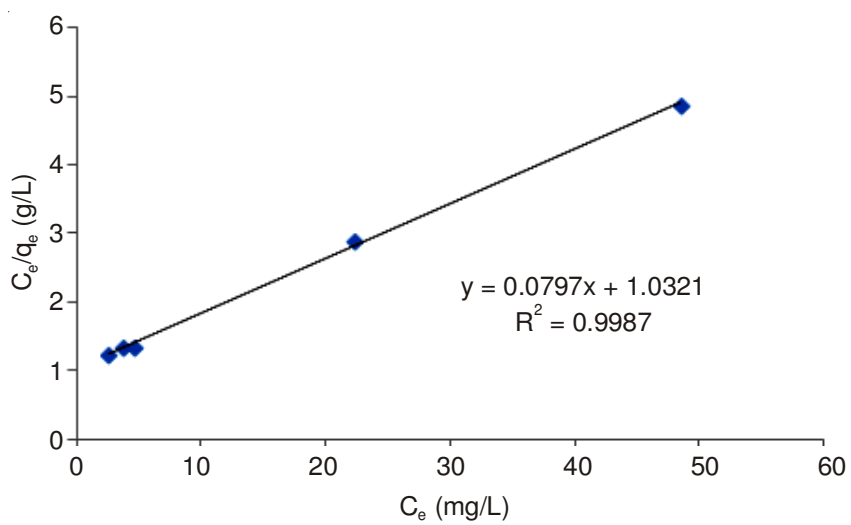

Fig. 12. Langmuir plot for solution of phosphate by paper mill sludge at room temperature

\begin{tabular}{ll}
\multicolumn{2}{c}{ TABLE-2 } \\
\multicolumn{2}{c}{ PROCESS NATURE OF SEPARATION FACTOR } \\
\hline \multicolumn{1}{c}{$\mathrm{R}_{\mathrm{L}}$ value } & \multicolumn{1}{c}{ Types of process } \\
\hline $\mathrm{R}_{\mathrm{L}}>1$ & Unfavorable \\
$\mathrm{R}_{\mathrm{L}}=1$ & Linear \\
$0<\mathrm{R}_{\mathrm{L}}<1$ & Favorable \\
$\mathrm{R}_{\mathrm{L}}=0$ & Irreversible \\
\hline
\end{tabular}

Freundlinch isotherm model: The Freundlich isotherm assume heterogeneous system with different energy of active sites and reversible adsorption, which is not restricted to monolayer formations ${ }^{23}$. The Freundlich constant can be obtained from a plot of $\log \mathrm{q}_{\mathrm{e}} v s . \log \mathrm{C}_{\mathrm{e}}$ (Fig. 13). The linear form of Freundlich isotherm as shown below;

$$
\log \mathrm{q}_{\mathrm{e}}=\log \mathrm{K}_{\mathrm{F}}+\frac{1}{\mathrm{n}} \log \mathrm{C}_{\mathrm{e}}
$$

where $\mathrm{K}_{\mathrm{F}}\left((\mathrm{mg} / \mathrm{g})(\mathrm{L} / \mathrm{mg})^{1 / \mathrm{n}}\right)$ indicates the relative adsorption capacity of the adsorbent related to bond energy and $\mathrm{n}$ is the heterogeneity factor representing the deviation from linearity of adsorption. Larger value of $\mathrm{K}_{\mathrm{F}}$ indicates the greater adsorption capacity while $\mathrm{n}$ values indicate the favorability of the adsorption process. If $\mathrm{n}$ is above unity, then the adsorption process is favorable.

Dubinin Raduskevich (D-R) isotherm model: The D-R isotherm analysis widely used in order to determine high degree of rectangularity ${ }^{24}$. The linear form of D-R isotherm equation is as follows:

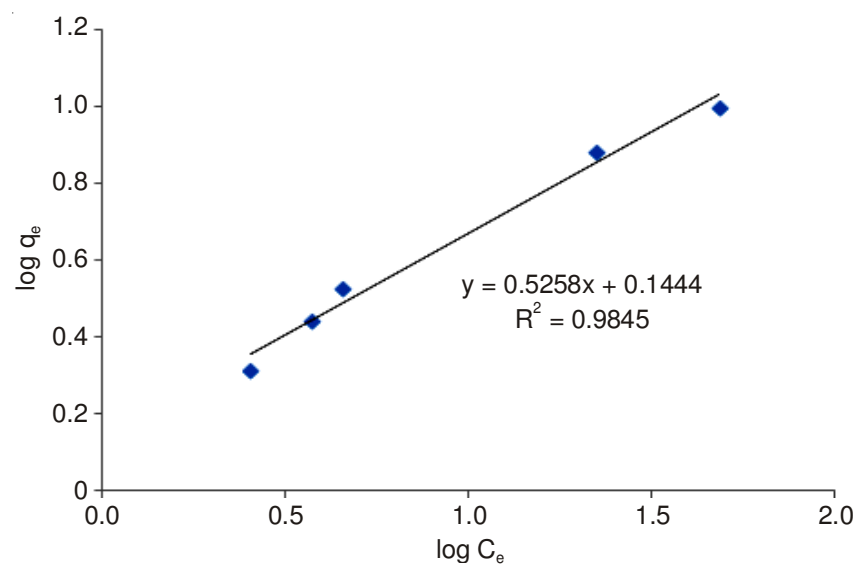

Fig. 13. Freundlich plot for solution of phosphate by paper mill sludge at room temperature

$$
\ln \mathrm{q}_{\mathrm{e}}=\ln \mathrm{q}_{\mathrm{m}}-\beta \varepsilon^{2}
$$

where $\beta\left(\mathrm{mol}^{2} / \mathrm{kJ}^{2}\right)$ represent adsorption energy constant obtained from slope of straight-line plot of $\ln \mathrm{q}_{\mathrm{e}} v s . \varepsilon^{2}$ (Fig. 14) and $\varepsilon$, the polanyi potential, can be calculated using following equation;

$$
\varepsilon=\mathrm{RT} \ln \left[1+1 / \mathrm{C}_{\mathrm{e}}\right]
$$

where $\mathrm{R}$ is the universal gas constant in $\mathrm{kJ} /(\mathrm{mol} \mathrm{K})$ and $\mathrm{T}$ is the temperature in Kelvin. The mean free energy, E $(\mathrm{kJ} / \mathrm{mol})$ (Table-4) can be obtained by the following equation;

$$
\mathrm{E}(\mathrm{kJ} / \mathrm{mol})=\left(2 \beta^{-0.5}\right)
$$

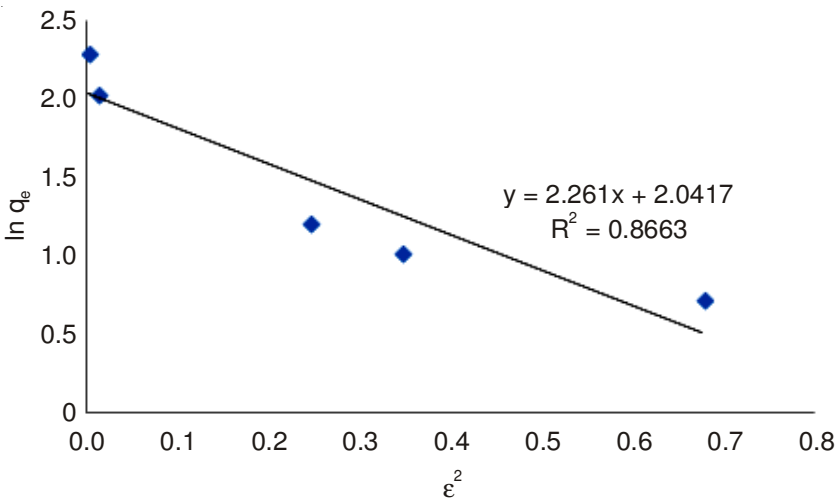

Fig. 14. D-R plot for solution of phosphate by paper mill sludge at room temperature

Temkin isotherm model: Another model for the analysis of indirect adsorbent/adsorbate interactions on adsorption isotherms is Temkin model ${ }^{25}$. Apart from that, this isotherm assumes that the heat of adsorption of all the molecules in the layer would decreases linearly with coverage and the adsorption is characterized by a uniform distribution of binding energies, up to some maximum binding energy. The linear form of Temkin isotherm equation is as follows:

$$
\mathrm{q}_{\mathrm{e}}=\beta \ln \mathrm{K}_{\mathrm{T}}+\beta \ln \mathrm{C}_{\mathrm{e}}
$$

where $\beta=\mathrm{RT} / \mathrm{b}_{\mathrm{T}}$. A plot of $\mathrm{q}_{\mathrm{e}} v s$. $\ln \mathrm{C}_{\mathrm{e}}$ (Fig. 15), constant $\mathrm{K}_{\mathrm{T}}$ and $b_{\mathrm{T}}$ can be found from intercept and slope. $\mathrm{K}_{\mathrm{T}}(\mathrm{L} / \mathrm{mg})$ represent Temkin constant related to the equilibrium binding energy while $b_{\mathrm{T}}(\mathrm{J} / \mathrm{mol})$ is Temkin constant related to the heat of adsorption as shown in Table-4. 


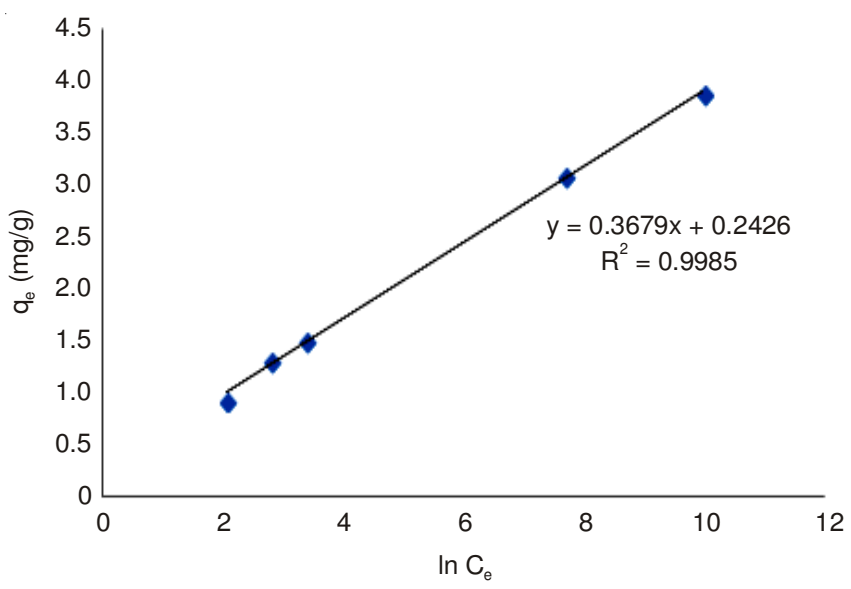

Fig. 15. Temkin plot for solution of phosphate by paper mill sludge at room temperature

\begin{tabular}{ccc}
\multicolumn{3}{c}{ TABLE-3 } \\
\multicolumn{3}{c}{$\mathrm{R}_{\mathrm{L}}$ VALUE AT DIFFERENT INITIAL } \\
CONCENTRATION OF PHOSPHATE \\
\hline \multirow{2}{*}{ No } & $\begin{array}{c}\text { Initial Phosphate } \\
\text { concentration (mg/L) }\end{array}$ & $\mathrm{R}_{\mathrm{L}}$ value \\
\hline 1 & 60 & 0.8364 \\
2 & 80 & 0.7769 \\
3 & 100 & 0.7414 \\
4 & 200 & 0.369 \\
5 & 300 & 0.2111 \\
\hline
\end{tabular}

Referring to Table-4, Langmuir isotherm model fitted well with the highest $\mathrm{R}^{2}=0.9987$ compared to the other three isotherm models. The maximum capacity at equilibrium, $\mathrm{Q}_{\mathrm{m}}$ was 12.65 $\mathrm{mg} / \mathrm{g}$ while $\mathrm{b}$ which denotes adsorption energy was $0.077 \mathrm{~L} / \mathrm{mg}$. The high correlation coefficient confirmed that monolayer adsorption of phosphate onto the paper mill sludge surface. The $R_{L}$ values which were in the range of 0.83 and 0.21 as shown in Table- 3 indicated that the adsorption process were favorable under studied condition. Temkin and Freundlich isotherm models also showed relatively good agreement with the $\mathrm{R}^{2}=0.9985$ and $\mathrm{R}^{2}=0.9845$, respectively.

The value of $\mathrm{K}_{\mathrm{T}}$ and $\mathrm{b}_{\mathrm{T}}$ of the Temkin isotherm was reported as $1.934 \mathrm{~L} / \mathrm{mg}$ and $6.734 \mathrm{~kJ} / \mathrm{mol}$ which explains equilibrium binding energy and the heat of adsorption, respectively. Meanwhile Freundlich constant for adsorption capacity, $\mathrm{K}_{\mathrm{F}}$ was $1.393 \mathrm{mg} / \mathrm{g}$. The $\mathrm{n}_{\mathrm{f}}$ value (indicator for adsorption intensity) calculated from the Freundlich model was 1.905 which in the range of $1<\mathrm{n}<10$, indicating favorable adsorption. This adsorptive behaviour implied that the adsorption also took place on a heterogeneous surface. Hence, it can be concluded that adsorption of phosphate by paper mill sludge followed multisorption process where both monolayer and bilayer adsorption present simultaneously in the surfaces of the sorbent but the former adsorption more predominant.

The applicability of the isotherm models to the adsorption behaviours can be judged by using the correlation coefficient $\left(R^{2}\right)$ values. The $R^{2}$ values of Freundlich and Temkin isotherms were higher than the Dubinin-Radushkevich isotherm $\left(\mathrm{R}^{2}=0.8663\right)$ but lower compared to Langmuir model. The adsorption equilibrium data fitted the isotherm models in the order of: Langmuir $>$ Temkin $>$ Freundlich $>$ DubininRadushkevich.

\begin{tabular}{ccccc}
\hline \multicolumn{5}{c}{ TABLE-4 } \\
\multicolumn{5}{c}{ ISOTHERM CONSTANTS AND REGRESSION DATA FOR } \\
\multicolumn{5}{c}{ ADSORPTION OF PHOSPHATE ON PAPER MILL SLUDGE } \\
\hline No. & Isotherm model & \multicolumn{2}{c}{ Isotherm constant } & $\mathrm{R}^{2}$ \\
\hline 1 & Langmuir & $\mathrm{Q}_{\mathrm{m}}(\mathrm{mg} / \mathrm{g})$ & 12.65 & 0.9987 \\
& & $\mathrm{~b}(\mathrm{~L} / \mathrm{mg})$ & 0.077 & \\
\hline 2 & Freundlich & $\mathrm{K}_{\mathrm{f}}((\mathrm{mg} / \mathrm{g})$ & 1.393 & 0.9845 \\
& & $(\mathrm{~L} / \mathrm{mg}) 1 / \mathrm{n})$ & & \\
& & $\mathrm{n}_{\mathrm{f}}$ & 1.905 & \\
\hline 3 & \multirow{4}{*}{ Temkin } & $\mathrm{K}_{\mathrm{T}}(\mathrm{L} / \mathrm{mg})$ & 1.934 & 0.9985 \\
& & $\mathrm{~b}_{\mathrm{T}}(\mathrm{kJ} / \mathrm{mol})$ & 6.734 & \\
\hline 4 & Dubinin- & $\mathrm{Q}_{\mathrm{m}}(\mathrm{mg} / \mathrm{g})$ & 7.704 & 0.8663 \\
& Radushkevich & $\mathrm{k}\left(\mathrm{mol}{ }^{2} \mathrm{~kJ}{ }^{2}\right)$ & 2.261 & \\
& & $\mathrm{E}(\mathrm{kJ} / \mathrm{mol})$ & 0.470 & \\
\hline
\end{tabular}

Comparison of maximum adsorption capacity $\left(Q_{m}\right)$ of phosphate for some low cost adsorbent: Finally, the performance of paper mill sludge was compared with some other low cost adsorbent as shown in Table-5. The obtained binding capacity clearly indicated that paper mill sludge is an effective adsorbent for phosphate removal from water.

\begin{tabular}{|c|c|c|c|}
\hline \multicolumn{4}{|c|}{$\begin{array}{c}\text { TABLE-5 } \\
\text { REPORTED ADSORPTION CAPACITIES }\left(\mathrm{Q}_{\mathrm{m}}\right) \text { OF } \\
\text { PHOSPHATE FOR SOME LOW-COST ADSORBENTS }\end{array}$} \\
\hline No & Adsorbent & $\begin{array}{c}\mathrm{Q}_{\mathrm{m}} \\
(\mathrm{mg} / \mathrm{g})\end{array}$ & Ref. \\
\hline 1 & Geothite & 0.286 & 26 \\
\hline 2 & Natural zeolite & 6.42 & 27 \\
\hline 3 & Na-Natural zeolite & 2.15 & 28 \\
\hline 4 & Synthetic iron oxide coated sand & 2.19 & 29 \\
\hline 5 & Coated crushed brick & 1.75 & 30 \\
\hline 6 & Naturally iron oxide coated sand & 0.88 & 30 \\
\hline 7 & Iron-hydroxide eggshell & 14.49 & 6 \\
\hline 8 & Iron oxide tailing & 8.21 & 30 \\
\hline 9 & Paper mill sludge & 12.65 & Present study \\
\hline
\end{tabular}

\section{Conclusion}

The raw paper mill sludge has the potential to be used as a low cost adsorbent for removal of phosphate from aqueous solutions effectively at $\mathrm{pH} 12$. The pseudo second-order model fits better than the pseudo first-order model for adsorption kinetic data and indicates the adsorption process is based on chemisorptions. The adsorption capacity for phosphate was increased with increasing temperature and indicates that the process was endothermic. The calculated $E_{a}$ is $37.01 \mathrm{~J} / \mathrm{mol}$ further suggests that the sorption of phosphate by paper mill sludge was based on chemical adsorption. Intraparticle diffusion was involved in the adsorption process but it is not a rate determining step. The equilibrium data were fitted well to Langmuir isotherm with maximum adsorption capacity of $12.65 \mathrm{mg} / \mathrm{g}$.

\section{ACKNOWLEDGEMENTS}

The authors expressed their gratitude to the University of Malaya for the Research Grant (RP006A-13SUS), IPPP grant PV076/2012A, High Impact Research Grant UM-MOHE UM. C/625/1/HIR/MOHE/F00004-21001 from the Ministry of Higher Education Malaysia (MOHE). 


\section{REFERENCES}

1. A.N. Abdul Aziz, Institutionalizing Solid Waste Management in Malaysia, Department of National Solid Waste Management, Ministry of Housing and Local Government Malaysia (2007).

2. T.A. O'Brien, S.J. Herbert and A.V. Barker, Commun. Soil Sci. Plant Anal., 34, 2229 (2003).

3. S. Navaee-Ardeh, F. Bertrand and P.R. Stuart, Dry Technol., 24, 863 (2006).

4. M. Hojamberdiev, Y. Kameshima, A. Nakajima, K. Okada and Z. Kadirova, J. Hazard. Mater., 151, 710 (2008)

5. K. Karageorgiou, M. Paschalis and G.N. Anastassakis, J. Hazard. Mater., 139, 447 (2007).

6. N.Y. Mezenner and A. Bensmaili, Chem. Eng. J., 147, 87 (2009).

7. N.R. Khalili, J.D. Vyas, W. Weangkaew, S.J. Westfall, S.J. Parulekar and R. Sherwood, Separ. Purif. Tech., 26, 295 (2002).

8. T. Wajima, M. Haga, K. Kuzawa, H. Ishimoto, O. Tamada, K. Ito, T. Nishiyama, R.T. Downs and J.F. Rakovan, J. Hazard. Mater., 132, 244 (2006).

9. J.H.A. Vinay Kumar, Y. Kameshima, A. Nakajima, K. Okada and K.J.D. McKenzie, J. Environ. Sci. Health, A41, 703 (2006).

10. K. Okada, Y. Ono, Y. Kameshima, A. Nakajima and K. MacKenzie, $J$. Hazard. Mater., 141, 622 (2007).

11. A. Mendez, J.M. Fidalgo, F. Guerrero and G. Gasco, J. Anal. Appl. Pyrolysis, 86, 66 (2009).

12. S. Gupta and B.V. Babu, Chem. Eng. J., 150, 352 (2009).
13. Y. Song, H.H. Hahn and E. Hoffmann, Chemosphere, 48, 1029 (2002).

14. M.W. Kamiyango, W.R.L. Masamba, S.M.I. Sajidu and E. Fabiano, J. Phys. Chem. Earth, 34, 850 (2009).

15. Y.S. Ho and G. McKay, Trans. I Chem. E, 76B, 332 (1998).

16. Y.S. Ho and G. McKay, J. Environ. Sci. Health, A34, 1179 (1999).

17. M.M. Castro López, M.C. Cela Pérez, M.S. Dopico García, J.S. López Vilarino, M.V. González Rodríguez and L.F. Barral Losada, Anal. Chim. Acta, 721, 68 (2012)

18. W.J. Weber Jr. and J.C. Morris, J. Sanit. Eng. Div., 89, 31 (1963).

19. N. Kannan and M.M. Sundaram, Dyes Pigments, 51, 25 (2001).

20. M. Kilic, E. Apaydin-Varol and A.E. Pütün, J. Hazard. Mater., 189, 397 (2011).

21. H. Nollet, M. Roels, P. Lutgen, P. Van der Meeren and W. Verstraete, Chemosphere, 53, 655 (2003).

22. I. Langmuir, J. Am. Chem. Soc., 40, 1361 (1918).

23. G. McKay, H.S. Blair and J.R. Gardner, J. Appl. Polym. Sci., 27, 3043 (1982).

24. M.M. Dubinin and L.V. Radushkevich, Chem. Zent., 1, 875 (1947).

25. M.J. Temkin and V. Pyzhev, Acta Physiochim. USSR, 12, 217 (1940).

26. S. Wang, X. Jin, H. Zhao and F. Wu, Aquat. Bot., 89, 23 (2008).

27. O.K. Borggaard, B. Raben-Lange, A.L. Gimsing and B.W. Strobel, Geoderma., 127, 270 (2005).

28. K. Sakadevan and H.J. Bavor, Water Res., 32, 393 (1998).

29. L. Zeng, X. Li and J. Liu, Water Res., 38, 1318 (2004).

30. N. Boujelben, J. Bouzid, Z. Elouear, M. Feki, F. Jamoussi and A. Montiel, J. Hazard. Mater., 151, 103 (2008). 